\title{
Giuseppe Pellizzi Prize 2018
}

The Club of Bologna (www.clubofbologna.org) in collaboration with the Accademia dei Georgofili organizes the third edition of the Giuseppe Pellizzi Prize, an international competition reserved to PhD Theses devoted to Farm Machinery and Mechanization topics. The prize is awarded concurrently with the agricultural machinery exhibition EIMA International, held in Bologna (Italy) every two years.

Applicants must have achieved a PhD with specific reference to the sector of Agricultural Machines and Mechanization under the following specific headings: i) Tractors and Engines; ii) Agricultural Machines and Mechanization; iii) Components and Materials; iv) Automation and Electronics.

To be eligible the Applicants must: i) be born after the $31^{\text {st }}$ December 1981; ii) have obtained the PhD title not before the $1^{\text {st }}$ January 2016; and iii) be presented by a Full Member of the Club of Bologna, who will act as Tutor.

The application should be submitted exclusively by e-mail to the Club of Bologna Secretary General (Prof. Marco Fiala; marco.fiala@unimi.it) using the Forms download from the Club of Bologna web site http://www.clubofbologna.org. The submission deadline is $30^{\text {th }}$ June 2018 .

The Management Committee of Club of Bologna will assess the presented PhD Theses and will select the three best ones. Winners will receive from FEDERUNACOMA a cash prize of 1200,800 and 500 Euro, for $1^{\text {st }}, 2^{\text {nd }}$ and $3^{\text {rd }}$ place, respectively. During the Giuseppe Pellizzi Prize 2018 award ceremony - organized in a special session of the $28^{\text {th }}$ Club of Bologna Members Meeting (10-11 November 2018 ) - the three winners will be asked for a short lecture on their PhD Thesis results. Finally they will be invited to attend - as guest experts, hosted by FEDERUNACOMA - to the Club of Bologna Full Members Meetings for a period of five years (up to 2023). 